\title{
Randomized Clinical Trial to Evaluate the Efficacy of Ashtamangal Ghrita Oral and Nasya in the Management of Cerebral Palsy
}

\author{
Research Article
}

\section{Shabnam Rajput ${ }^{1}$, Kalpana Patni2*}

1. PG Scholar, Department of Kaumarabhritya, State Ayurvedic College and Hospital, Lucknow, India. 2. Assistant Professor, Department of Kaumarbhritya, IMS BHU, Varanasi, India.

\begin{abstract}
Background: Cerebral palsy is one of the most common childhood disabilities, which hinder the development of a child, causing extensive suffering to affected children and their families. According to world health organization about $10 \%$ of population have some form of disabilities. Cerebral Palsy can be compared with Vatavyadhi (neurological disorder) manifested in various form like sarvangavata (quadri-plegia), pakshaghata (hemiparesis), ekangavata(monoplegia), pangu and khanja (motor disorder), kampavata, jadatva (mental retadation), mukatva (dumbness) etc. Objective: To evaluate the efficacy of Ashtamangal ghrita, in the form of oral medication and as nasya in the management of cerebral palsy. Material and Methods: Total 24 Children with physical and mental developmental disabilities of of age group 01 to 10 years of either sex were randomly divided into two groups, group A received Ashtamangal ghrita (orally) - $1 \mathrm{ml} / \mathrm{kg}$ body weight in two divided doses for 3 months and Group B received Pratimarsh Nasya with Ashtamangal ghrita - 2 drops in each nostril 2 times a day for 3 months. Assessments were done on the basis of 5 point grading score of Clinical symptoms of Cerebral Palsy as per standard classification scale for CP, i.e, motor functions were assessed on the basis of CDC Grading Scale for Motor milestones and Teacher's drooling test. Follow up visit was on every 15th day. Result: Overall effect of therapy shows that there was $34.79 \%$ improvement in group A \& $37.74 \%$ improvement in group B. Results were slightly superior in group B than group A in most of the parameters. Although intergroup comparison of both groups was notsignificant or there were no differences in both groups statistically. Group A was slightly superior than group B in following parameters -Head holding, sitting, teacher drooling scale and spasticity. In all the other parameters group B was slightly superior. Conclusion: Clinical efficacy of both Ashtamangal ghrita orally and as nasya on various parameters of Cerebral Palsy showed that both were effective, safe and comparable.
\end{abstract}

Key Words: Ashtamangal ghrita, Cerebral Palsy, Nasya, Motor milestones.

\section{Introduction}

Cerebral palsy (CP) is one of the most common childhood disabilities, which hinder the development of a child, causing extensive suffering to affected children and their families. Cerebral palsy is caused by non progressive damage to brain before, during or after birth. It is not a single entity but a term given to wide variety of neuromotor impairments, secondary to a lesion in the developing brain. It includes heterogeneous clinical states of unpredictable etiology and severity ranging from minor to total handicap (1). Motor disorders of CP often accompany disturbances of sensation, perception, communication, cognition, and behavior. Cerebral palsy can be classified into - Spastic, Hypotonic (ataxic), Extrapyramidal, Cerebellar involvement \& mixed type. Spastic CP is the most

* Corresponding Author:

\section{Kalpana Patni}

Assistant Professor,

Department of Kaumarbhritya,

IMS BHU,

Varanasi, India

Email Id: kalpana.patni@gmail.com common form $(65 \%)(2)$. The prevalence of cerebral palsy in children is $2 / 1000$ live births (3). According to world health organization about $10 \%$ of population have some form of disabilities (4). Cerebral Palsy is rendered incurable although several advances and researches in the management are going on in various parts of globe to improve the physical, mental and functional status of the CP child. Cerebral palsy cannot be co-related with any single disease entity in Ayurveda. Cerebral Palsy can be compared with Vatavyadhi(neurological disorder) which may manifest itself in various form like pakshaghata (hemiparesis), sarvangavata (quadriplegia), ekangavata(monoplegia), pangu and khanja (locomotor disorder), kampavata, jadatva (mental retardation), mukatva (dumbness) etc. CP can be stated as Janma Bala Pravritta Vyadhi (congenital disorder). Also, CP can be considered as Shrio marmabhighataja Vata Vyadhi (disease caused due to the injury of head). $(5,6)$ Features of cerebral palsy can also be correlated with Skanda graha in which hata- ekpaksh (complete or partial loss of motor activity of one half of the body), mukha vakrata (facial palsy), lalasrav (excessive salivation) etc. are the main symptoms (7). Other factors like inappropriate ritu (ovulation cycle), kshetra (uterus), ambu (amniotic fluid and fetal nutrition) and bija (sperm and ovum) (8), dauhrida-avamanana 
(neglect of urges of pregnant women) (9), incompatible garbhavriddhi-karabhava (normal requisite for growth and development of fetus) $(10,11)$ and improper garbhiniparicharya (antenatal regimen) (12) may be contributory causing undesirable effects on fetus hindering it's normal growth and development, thereby leading to many disorders, deformities and even death.

\section{Materials and Methods}

\section{Protocol of Clinical Study}

- Consent - Written and informed consent of study subjects was taken before inclusion in the trial.

- IEC approval - Approval for clinical trial on human being was obtained from institutional ethical committee of S.A.C. \& Hospital, Lucknow, U.P. ( No.IEC /AYM/ 072 -2017). The study was registered in Clinical trial registry of India (CTRI registration no.- CTRI/2018/06/014415).

- Proforma - Proforma incorporating detailed profile of study subjects with chief complaints, history of present illness, sign \& symptoms and assessment was prepared.

Following materials and methods have been adopted for conducting present trial-

- Type of study- Randomized, two groups comparative clinical trial.

\section{Selection of cases and group allocation-}

- Age- 1-10 years

- Sample size- Total 31 patients were selected from OPD and IPD of Kaumarabhritya department of State Ayurvedic College and Hospital, Lucknow \& randomly allocated in two groups- 15 patients in group A \& 16 patients in group B. During trial 7 patients were dropout- 3 patients from group A \& 4 patients from group B, so complete study was on 24 patients.

- Group A- Ashtamangal ghrita (orally) - $1 \mathrm{ml} / \mathrm{kg}$ body weight in two divided doses for 3 months.

- Group B- Pratimarsh Nasya with Ashtamangal ghrita - 2 drops in each nostril 2 times a day for 3 months.

Shashtikashali pinda sweda for 20 days daily for 30 minutes on whole body was given in both groups, temperature of the pottali was lukewarm \& tolerable to the child, after 10 days interval course was repeated. Such 3 cycles were done.

\section{Preparation of Trial Drug}

Ashtamangal ghrita was mentioned in bala roga prakarana in Yoga Ratnakara. The crude drugs present in 'Ashtamangal Ghrita' were Vacha (Acorus calamus Linn.), Brahmi (Bacopa monnieri Linn.), Kushta (Saussurea lappa Clarke), Piper (Piper longum Linn.), Sariva (Hemidesus indicus Linn.), and Sarshap (Brassica compestris Linn.) in equal proportion along with Saindhava (sodium chloride) and Go-Ghrita. Ashtamangal ghrita was prepared according to sneha kalpana procedure described in Sharangdhara Samhita. In both the groups the used drug was Ashtamangal ghrita but there was difference in preparation. For nasya purpose, mridu paka of ghrita was done \& for oral madhyam paka of ghrita was done.

- Dose deciding criteria - Dose of Ashtamangal ghrita orally-Dose of Ashtamangal ghrita was decided on basis of classical reference as mentioned in Sharangadhar Samhita Sneha kalpana adhyaya 9/1, dose being 1 Pala i.e. 48 grams (approx $50 \mathrm{ml}$ ) then dividing by average adult body weight $50 \mathrm{~kg}$ (general rule to get pediatric dose as per kg body weight) so the dose of ghrita was $1 \mathrm{ml} / \mathrm{kg}$ body weight in two divided doses. Pratimarsh Nasya- Sushruta and Vagbhat have explained the dose in the form of bindus (drops). Thus, dose of Pratimarsh nasya was 2 drops in each nostril for 2 times in a day.

- Duration of trial - It was a trial of 90 days. The clinical assessment of patients was carried out during the trial $1^{\text {st }}$ on $30^{\text {th }}$ day, $2^{\text {nd }}$ on $60^{\text {th }}$ day and $3^{\text {rd }}$ on $90^{\text {th }}$ day and then after trial.

- Criteria to be adopted - For conducting the trial following criteria has been adopted-

- Inclusion criteria - Children with $\mathrm{CP}$ aged 1 year to 10 years of either sex, with physical and mental developmental disabilities (Delayed milestones) along with already diagnosed cases of $\mathrm{CP}$ are included in the study.

- Exclusion criteria - Children of $\mathrm{CP}$ with major congenital disorder \& other disease status viz. Juvenile DM, Acute infections, severe systemic illness etc. or children with any progressive neurologic anomalies or Muscular dystrophy are excluded from the study

- Discontinuation criteria - Parents/guardians not willing to continue treatment or patients who develop life threatening complications during treatment.

\section{Assessment criteria}

Grading of Clinical symptoms of Cerebral Palsy depending on severity was done on $0-5$ point grading score pattern as per standard classification scale for CP, i.e, CDC Grading Scale for Motor milestonesHead Holding, Sitting, Standing, Fine motor and Language. Also grading done for performance (Making triangle between three points) Mental status (Happiness) Memory (After showing 5 familiar objects) and for drooling, Teacher's drooling scale.

Side effect evaluation criteria- Clinical criteria were adopted to rule out possible side effects of the study drug. It included the documentation of information related to change in appetite, sleep, abdominal features, drowsiness, pain, irritability etc.

- Statistical analysis - Observations documented during study were analyzed and findings were evaluated by using statistical analysis to establish efficacy. Wilcoxon Test, Mann Whitney Test and ttest, were used for the statistical analysis.

- Drug compliance- If there is more than or equal to $80 \%$ compliance, the participant would be continued in the trial. 
The compliance need to be assessed at each visit during follow up by counting the no. of empty container/bottles/sachets returned and approximate quantity consumed by the patient.

\section{Patient information and consent}

Prior to trial, the principal investigator had given the patient verbal and written information about the trial in the form the participant/guardian/parent (s) can read and understand. A voluntary, signed witnessed informed consent was obtained from the participant prior to any clinical trial.

\section{Observations}

\section{Demographic Observation}

Distribution according to age shows that maximum number of patients in both groups were $55 \%$ between age 1-4 years of age group, out of which in group A 74\% were of age group 1-4 years, in group B $38 \%$ were of age group 1-4 years. Distribution according to sex shows the male predominance in group A $67 \%$ and in group B - 63\%. Overall observation shows male predominance. Distribution according to socio-economic status shows that maximum patients were of lower-middle class $-60 \%$ in group A and $69 \%$ in group B. distribution according to immunization status shows that in group A $-67 \%$ patients had incomplete immunization status and in group B $-56 \%$ patients were properly immunized.

\section{Clinical Observation}

Distribution according to history of infectious disease shows that in group A $-13.33 \%$ patients had history of chickenpox and $6.66 \%$ patients had history of other infection and in $80 \%$ patients there were no history of infection. In group B 19\% patients had history of infection and in maximum patients- $81 \%$ had no history of infection. Distribution according to age of weaning shows that the total $19 \%$ patients have the age of weaning at 6 month of age in both the groups. Delayed age of weaning was $39 \%$ at 1 year of age and $23 \%$ at 2 year of age. Distribution according to tone shows that in group A maximum patients $60 \%$ were of hypertonic and in group B maximum patients were hypotonic. In group B 19\% patients were of normal tone. Distribution according to involuntary movements shows that in $47 \%$ in group $\mathrm{A}$ there were no involuntary movements, seizures were found in $33 \%$ in group A and $38 \%$ in group B, Dystonia were found in $13 \%$ in group $\mathrm{A}$ and $6 \%$ in group $\mathrm{B}$, Athetosis were found in $7 \%$ in group $A$ and $13 \%$ in group B. Distribution according to gait shows that in group A maximum $80 \%$ patients were diplegic and in group B maximum patients $44 \%$ were unable to walk followed by diplegic gait in $38 \%$ patients. Distribution according to type of motor deficit shows that in group A maximum patients $80 \%$ were diplegic, $20 \%$ quadriplegic. In group B 44\% patients were quadriplegic, $38 \%$ diplegic, $19 \%$ patients were hemiplegic. Distribution according to past history shows that in group A $13 \%$ patients were showing past history of high grade fever, $13 \%$ neonatal jaundice, 7\% showing inconsolable cry. In group B 13 $\%$ patients were showing past history of convulsions, 6 $\%$ patients showing pneumonia, $6 \%$ patients showing diarrhoea, 6\% showing septicaemia. Distribution according to antenatal history shows that in group A 20 $\%$ cases were showing antenatal history of hypothyroidism, $7 \%$ cases showing high grade fever \& $7 \%$ cases fever with rash. In group B $23 \%$ cases were showing antenatal history of hypothyroidism, $6 \%$ bad obstetric history, $6 \%$ high grade fever, 3\% cases dehydration, fever with rash \& jaundice. Distribution according to natal history shows that most of the cases were showing prolonged $2^{\text {nd }}$ stage of labour, LSCS, leaking or bleeding PV, history of instrumentation, decreased fetal movement. Distribution according to post natal history shows that most of the cases were showing LBW, delayed cry, IUGR, preterm, fever, neonatal jaundice, septicaemia. Distribution according to reflexes shows that in group A $33 \%$ were showing diminished reflexes, $27 \%$ exaggerated, $7 \%$ cases can't be assessed due to hyperactivity and $33 \%$ cases were normal. In group B 35\% cases were showing diminished reflexes, $29 \%$ exaggerated, $29 \%$ were normal \& in $3 \%$ cases reflexes were absent.

\section{Therapeutic Observations - Milestones}

Table No.1 : Effect of Treatment on Head Holding in both the Groups

\begin{tabular}{|c|c|c|c|c|c|c|c|c|c|c|}
\hline \multirow{2}{*}{$\begin{array}{l}\text { Head } \\
\text { holding }\end{array}$} & \multicolumn{5}{|c|}{ Group A } & \multicolumn{5}{|c|}{ Group B } \\
\hline & Mean & SD & $\%$ imp & z-value & p-value & Mean & SD & $\%$ imp & z-value & p-value \\
\hline BT & 2.83 & 2.17 & - & - & - & 3.75 & 1.96 & - & 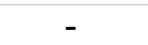 & - \\
\hline Day 30 & 2.83 & 2.17 & 0.00 & 0.00 & 1.000 & 3.75 & 1.96 & 0.00 & 0.00 & 1.000 \\
\hline Day 60 & 2.83 & 2.17 & 0.00 & 0.00 & 1.000 & 4.00 & 1.65 & 6.67 & -1.73 & 0.083 \\
\hline $\mathrm{AT}$ & 3.25 & 1.86 & 14.71 & -2.24 & 0.025 & 4.25 & 1.22 & 13.33 & -1.86 & 0.063 \\
\hline $\mathrm{AF}$ & 3.25 & 1.86 & 14.71 & -2.24 & 0.025 & 4.25 & 1.22 & 13.33 & -1.86 & 0.063 \\
\hline
\end{tabular}

Table No.2 : Effect of Treatment on Sitting in both the Groups

\begin{tabular}{|c|c|c|c|c|c|c|c|c|c|c|}
\hline \multirow{2}{*}{ Sitting } & \multicolumn{5}{|c|}{ Group A } & \multicolumn{5}{|c|}{ Group B } \\
\hline & Mean & SD & $\%$ imp & z-value & p-value & Mean & SD & $\%$ imp & z-value & p-value \\
\hline BT & 1.58 & 1.73 & - & - & - & 2.42 & 1.98 & - & - & - \\
\hline Day 30 & 1.67 & 1.72 & 5.26 & -1.00 & 0.317 & 2.58 & 1.78 & 6.90 & -1.41 & 0.157 \\
\hline Day 60 & 1.92 & 1.62 & 21.05 & -2.00 & 0.046 & 2.92 & 1.78 & 20.69 & -2.45 & 0.014 \\
\hline AT & 2.33 & 1.56 & 47.37 & -3.00 & 0.003 & 3.50 & 1.57 & 44.83 & -2.92 & 0.004 \\
\hline $\mathrm{AF}$ & 2.33 & 1.56 & 47.37 & -3.00 & 0.003 & 3.50 & 1.57 & 44.83 & -2.92 & 0.004 \\
\hline
\end{tabular}


In group A significant improvement were found from BT to Day $60(21.05 \%, \mathrm{p}=0.046)$, AT $(47.37 \%, \mathrm{p}=0.003)$ and $\mathrm{AF}(47.37 \%, \mathrm{p}=0.003)$. In group B significant improvement were found from BT to Day 60 (20.69\%, 0.014), AT (44.83, $\mathrm{p}=0.004)$ and $\mathrm{AF}(44.83 \%, \mathrm{p}=0.004)$. Group A showed slightly superior results than group $\mathrm{B}$.

Table No. 3: Effect of Treatment on Standing in both the Groups

\begin{tabular}{|c|c|c|c|c|c|c|c|c|c|c|}
\hline \multirow{2}{*}{ Standing } & \multicolumn{5}{|c|}{ Group A } & \multicolumn{5}{|c|}{ Group B } \\
\hline & Mean & SD & $\%$ imp & z-value & p-value & Mean & SD & \% imp & z-value & p-value \\
\hline BT & 1.08 & 1.44 & - & - & - & 1.50 & 1.73 & - & - & - \\
\hline Day 30 & 1.17 & 1.40 & 7.69 & -1.00 & 0.317 & 1.58 & 1.68 & 5.56 & -1.00 & 0.317 \\
\hline Day 60 & 1.25 & 1.42 & 15.38 & -1.00 & 0.317 & 2.08 & 1.51 & 38.89 & -2.65 & 0.008 \\
\hline $\mathrm{AT}$ & 1.75 & 1.36 & 61.54 & -2.53 & 0.011 & 2.50 & 1.24 & 66.67 & -2.97 & 0.003 \\
\hline $\mathrm{AF}$ & 1.75 & 1.36 & 61.54 & -2.53 & 0.011 & 2.50 & 1.24 & 66.67 & -2.97 & 0.003 \\
\hline
\end{tabular}

In group A significant improvement were found from BT to AT $(61.54 \%, \mathrm{p}=0.011)$ and $\mathrm{AF}(61.54 \%, \mathrm{p}=0.011)$. In group B significant improvement were found from BT to Day $60(38.89 \%, 0.008)$, AT $(66.67, \mathrm{p}=0.003)$ and AF $(66.37 \%, p=0.003)$. Group B showed superior results than group A.

Table No.4 : Effect of Treatment on Fine motor in both the Groups

\section{Fine}

motor

\begin{tabular}{|l|r|r|r|r|r|}
\hline motor & Mean & \multicolumn{1}{c|}{ SD } & \% imp & z-value & p-value \\
\hline BT & 1.83 & 1.34 & - & - & - \\
\hline Day 30 & 1.83 & 1.34 & 0.00 & 0.00 & 1.000 \\
\hline Day 60 & 1.83 & 1.34 & 0.00 & 0.00 & 1.000 \\
\hline AT & 2.67 & 1.07 & 45.45 & -3.16 & $\mathbf{0 . 0 0 2}$ \\
\hline AF & 2.67 & 1.07 & 45.45 & -3.16 & $\mathbf{0 . 0 0 2}$ \\
\hline
\end{tabular}

\begin{tabular}{|r|}
\hline Mean \\
\hline 1.92 \\
\hline 2.00 \\
\hline 2.42 \\
\hline 3.00 \\
\hline 3.00 \\
\hline
\end{tabular}

\begin{tabular}{|c|c|}
\hline SD & $\%$ \\
\hline 1.56 & \\
1.48 & \\
1.31 & 2 \\
1.21 & 5 \\
1.21 & 5
\end{tabular}

Group B

In group A significant improvement were found from BT to AT $(45.45 \%, \mathrm{p}=0.002)$ and AF $(45.45 \%, \mathrm{p}=0.002)$. In group B significant improvement were found from BT to Day $60(26.09 \%, 0.014)$, AT $(56.52, \mathrm{p}=0.004)$ and AF $(56.52 \%, \mathrm{p}=0.004)$. Group B showed slightly superior results than group A.

Table No. 5: Effect of Treatment on Personal/social in both the Groups

\begin{tabular}{|c|c|c|c|c|c|c|c|c|c|c|}
\hline \multirow{2}{*}{$\begin{array}{l}\text { Personal/ } \\
\text { social }\end{array}$} & \multicolumn{5}{|c|}{ Group A } & \multicolumn{5}{|c|}{ Group B } \\
\hline & Mean & SD & $\%$ imp & z-value & p-value & Mean & SD & \% imp & z-value & p-value \\
\hline BT & 3.08 & 1.78 & - & - & - & 3.50 & 1.98 & - & - & - \\
\hline Day 30 & 3.08 & 1.78 & 0.00 & 0.00 & 1.000 & 3.67 & 1.83 & 4.76 & -1.41 & 0.157 \\
\hline Day 60 & 3.17 & 1.64 & 2.70 & -1.00 & 0.317 & 4.00 & 1.60 & 14.29 & -2.45 & 0.014 \\
\hline AT & 3.75 & 1.48 & 21.62 & -2.83 & 0.005 & 4.50 & 1.38 & 28.57 & -2.64 & 0.008 \\
\hline $\mathrm{AF}$ & 3.75 & 1.48 & 21.62 & -2.83 & 0.005 & 4.50 & 1.38 & 28.57 & -2.64 & 0.008 \\
\hline
\end{tabular}

In group A significant improvement were found from BT to AT $(21.62 \%, \mathrm{p}=0.005)$ and $\mathrm{AF}(21.62 \%, \mathrm{p}=0.005)$. In group B significant improvement were found from BT to Day $60(14.29 \%, 0.014)$, AT $(28.57 \%, \mathrm{p}=0.008)$ and AF $(28.57 \%, \mathrm{p}=0.008)$. Group B showed slightly superior results than group A.

Table No. 6: Effect of Treatment on Mental status in both the Groups

\begin{tabular}{|c|c|c|c|c|c|c|c|c|c|c|}
\hline \multirow{2}{*}{$\begin{array}{l}\text { Mental } \\
\text { status }\end{array}$} & \multicolumn{5}{|c|}{ Group A } & \multicolumn{5}{|c|}{ Group B } \\
\hline & Mean & SD & $\%$ imp & z-value & p-value & Mean & SD & $\%$ imp & z-value & p-value \\
\hline BT & 1.08 & 0.67 & - & - & - & 1.25 & 0.87 & - & - & - \\
\hline Day 30 & 1.08 & 0.67 & 0.00 & 0.00 & 1.000 & 1.42 & 0.79 & 13.33 & -1.41 & 0.157 \\
\hline Day 60 & 1.17 & 0.72 & 7.69 & -1.00 & 0.317 & 1.58 & 0.67 & 26.67 & -2.00 & 0.046 \\
\hline AT & 1.42 & 0.67 & 30.77 & -2.00 & 0.046 & 1.67 & 0.65 & 33.33 & -2.24 & 0.025 \\
\hline $\mathrm{AF}$ & 1.42 & 0.67 & 30.77 & -2.00 & 0.046 & 1.67 & 0.65 & 33.33 & -2.24 & 0.025 \\
\hline
\end{tabular}

In group A significant improvement were found from BT to AT $(30.77 \%, p=0.046)$ and $\mathrm{AF}(30.77 \%, \mathrm{p}=0.046)$. In group B significant improvement were found from BT to Day $60(26.67 \%, 0.046)$, AT $(33.33 \%, \mathrm{p}=0.025)$ and $\mathrm{AF}$ $(33.33 \%, \mathrm{p}=0.025)$. Group B showed slightly superior results than group A.

Table No.7: Effect of Treatment on Language in both the Groups

\begin{tabular}{|c|c|c|c|c|c|c|c|c|c|c|}
\hline \multirow{2}{*}{$\begin{array}{c}\text { Langua } \\
\text { ge }\end{array}$} & $\begin{array}{c}\text { Group } \\
\text { A }\end{array}$ & $\begin{array}{c}\text { Group } \\
\text { B }\end{array}$ & & & & & & & & \\
\hline & Mean & SD & $\%$ imp & z-value & p-value & Mean & SD & $\%$ imp & z-value & p-value \\
\hline BT & 1.92 & 1.38 & - & - & - & 2.83 & 1.80 & - & - & - \\
\hline Day 30 & 1.92 & 1.38 & 0.00 & 0.00 & 1.000 & 2.83 & 1.80 & 0.00 & 0.00 & 1.000 \\
\hline
\end{tabular}




\begin{tabular}{|c|c|c|c|c|c|c|c|c|c|c|}
\hline Day 60 & 1.92 & 1.38 & 0.00 & 0.00 & 1.000 & 3.00 & 1.65 & 5.88 & -1.41 & 0.157 \\
\hline AT & 2.33 & 1.07 & 21.74 & -2.24 & $\mathbf{0 . 0 2 5}$ & 3.33 & 1.56 & 17.65 & -2.45 & $\mathbf{0 . 0 1 4}$ \\
\hline AF & 2.33 & 1.07 & 21.74 & -2.24 & $\mathbf{0 . 0 2 5}$ & 3.33 & 1.56 & 17.65 & -2.45 & $\mathbf{0 . 0 1 4}$ \\
\hline
\end{tabular}

In group A significant improvement were found from BT to AT $(21.74 \%, \mathrm{p}=0.025)$ and $\mathrm{AF}(21.74 \%, \mathrm{p}=0.025)$. In group B significant improvement were found from BT to AT $(17.65 \%, p=0.014)$ and $\mathrm{AF}(17.65 \%, \mathrm{p}=0.014)$. Group B showed slightly superior results than group A.

Table No.8 : Effect of Treatment on Performance in both the Groups

\begin{tabular}{|c|c|c|c|c|c|c|c|c|c|c|}
\hline \multirow{2}{*}{ Performance } & \multicolumn{5}{|c|}{ Group A } & \multicolumn{5}{|c|}{ Group B } \\
\hline & Mean & SD & $\%$ imp & z-value & p-value & Mean & SD & $\%$ imp & z-value & p-value \\
\hline BT & 0.25 & 0.62 & - & - & - & 0.33 & 0.78 & - & - & - \\
\hline Day 30 & 0.25 & 0.62 & 0.00 & 0.00 & 1.000 & 0.33 & 0.78 & 0.00 & 0.00 & 1.000 \\
\hline Day 60 & 0.25 & 0.62 & 0.00 & 0.00 & 1.000 & 0.83 & 0.83 & 150.00 & -2.12 & 0.034 \\
\hline AT & 0.50 & 0.80 & 100.00 & -1.73 & 0.083 & 1.00 & 0.74 & 200.00 & -2.53 & 0.011 \\
\hline $\mathrm{AF}$ & 0.50 & 0.80 & 100.00 & -1.73 & 0.083 & 1.00 & 0.74 & 200.00 & -2.53 & 0.011 \\
\hline
\end{tabular}

In group A no significant improvement was found from BT to any follow up and AF as well (p>0.05). In group B significant improvement were found from BT to Day $60(150 \%, p=0.034)$, AT $(200 \%, p=0.011)$ and AF $(200 \%, p=0.011)$. Group B showed superior results than group A.

Table No.9 : Effect of Treatment on Memory in both the Groups

\begin{tabular}{|c|c|c|c|c|c|c|c|c|c|c|}
\hline \multirow{2}{*}{ Memory } & \multicolumn{5}{|c|}{ Group A } & \multicolumn{5}{|c|}{ Group B } \\
\hline & Mean & SD & $\%$ imp & z-value & p-value & Mean & SD & $\%$ imp & z-value & p-value \\
\hline BT & 0.33 & 0.89 & - & - & - & 1.00 & 1.71 & & & \\
\hline Day 30 & 0.33 & 0.89 & 0.00 & 0.00 & 1.000 & 1.00 & 1.71 & 0.00 & 0.00 & 1.000 \\
\hline Day 60 & 0.33 & 0.89 & 0.00 & 0.00 & 1.000 & 1.08 & 1.68 & 8.33 & -1.00 & 0.317 \\
\hline AT & 0.42 & 1.00 & & -1.00 & 0.317 & 1.25 & 1.66 & 25.00 & -1.73 & 0.083 \\
\hline $\mathrm{AF}$ & 0.42 & 1.00 & 25.00 & -1.00 & 0.317 & 1.25 & 1.66 & 25.00 & -1.73 & 0.083 \\
\hline
\end{tabular}
$(\mathrm{p}>0.05)$.

In group A \& B both, no significant improvement was found from BT to any follow up and AT as well

Table No.10 : Effect of Treatment on Teacher drooling scale in both the Groups

\begin{tabular}{|c|c|c|c|c|c|c|c|c|c|c|}
\hline \multirow{2}{*}{$\begin{array}{l}\text { Teacher } \\
\text { drooling } \\
\text { scale }\end{array}$} & \multicolumn{5}{|c|}{ Group A } & \multicolumn{5}{|c|}{ Group B } \\
\hline & Mean & SD & $\% \operatorname{imp}$ & z-value & p-value & Mean & SD & $\%$ imp & z-value & p-value \\
\hline BT & 1.00 & 1.13 & - & - & - & & 1.08 & - & - & - \\
\hline Day 30 & & & 25.00 & -1.73 & & & 1.03 & 9.09 & -1.00 & 0.317 \\
\hline Day 60 & 0.67 & 0.78 & .33 & -1.63 & & & 0.67 & 36.36 & -1.63 & 0.102 \\
\hline AT & 0.1 & 0.39 & 83.33 & -2.46 & & & 0.45 & 72.73 & -2.27 & 0.023 \\
\hline $\mathrm{AF}$ & 0.17 & 0.39 & 83.33 & -2.46 & 0.014 & 0.25 & 0.45 & 72.73 & -2.27 & 0.023 \\
\hline
\end{tabular}

In group A significant improvement were found from BT to AT $(83.33 \%, \mathrm{p}=0.014)$ and $\mathrm{AF}(83.33 \%, \mathrm{p}=0.014)$. In group B significant improvement were found from BT to AT $(72.73 \%, \mathrm{p}=0.023)$ and $\mathrm{AF}(72.73 \%, \mathrm{p}=0.023)$. Group A showed slightly superior results than group B.

Table No.11 : Intergroup Comparison of Milestone Parameters between the groups

\begin{tabular}{|c|c|c|c|c|c|c|c|}
\hline \multirow{2}{*}{ Milestones } & & \multicolumn{2}{|c|}{ Group A } & \multicolumn{2}{|c|}{ Group B } & \multicolumn{2}{|c|}{ Mann Whitney Test } \\
\hline & & Mean & SD & Mean & SD & U-value & p-value \\
\hline \multirow{5}{*}{ Head holding } & BT & 2.83 & 2.17 & 3.75 & 1.96 & 54.00 & 0.319 \\
\hline & Day 30 & 2.83 & 2.17 & 3.75 & 1.96 & 54.00 & 0.319 \\
\hline & Day 60 & 2.83 & 2.17 & 4.00 & 1.65 & 49.00 & 0.198 \\
\hline & AT & 3.25 & 1.86 & 4.25 & 1.22 & 51.00 & 0.242 \\
\hline & $\mathrm{AF}$ & 3.25 & 1.86 & 4.25 & 1.22 & 51.00 & 0.242 \\
\hline \multirow{5}{*}{ Sitting } & BT & 1.58 & 1.73 & 2.42 & 1.98 & 54.50 & 0.319 \\
\hline & Day 30 & 1.67 & 1.72 & 2.58 & 1.78 & 49.00 & 0.198 \\
\hline & Day 60 & 1.92 & 1.62 & 2.92 & 1.78 & 49.00 & 0.198 \\
\hline & AT & 2.33 & 1.56 & 3.50 & 1.57 & 41.00 & 0.078 \\
\hline & $\mathrm{AF}$ & 2.33 & 1.56 & 3.50 & 1.57 & 41.00 & 0.078 \\
\hline
\end{tabular}




\begin{tabular}{|c|c|c|c|c|c|c|c|}
\hline \multirow{5}{*}{ Standing } & BT & 1.08 & 1.44 & 1.50 & 1.73 & 61.50 & 0.551 \\
\hline & Day 30 & 1.17 & 1.40 & 1.58 & 1.68 & 61.50 & 0.551 \\
\hline & Day 60 & 1.25 & 1.42 & 2.08 & 1.51 & 44.00 & 0.114 \\
\hline & AT & 1.75 & 1.36 & 2.50 & 1.24 & 47.00 & 0.160 \\
\hline & $\mathrm{AF}$ & 1.75 & 1.36 & 2.50 & 1.24 & 47.00 & 0.160 \\
\hline \multirow{5}{*}{ Fine motor } & BT & 1.83 & 1.34 & 1.92 & 1.56 & 70.00 & 0.932 \\
\hline & Day 30 & 1.83 & 1.34 & 2.00 & 1.48 & 71.00 & 0.977 \\
\hline & Day 60 & 1.83 & 1.34 & 2.42 & 1.31 & 52.50 & 0.266 \\
\hline & AT & 2.67 & 1.07 & 3.00 & 1.21 & 63.00 & 0.630 \\
\hline & $\mathrm{AF}$ & 2.67 & 1.07 & 3.00 & 1.21 & 63.00 & 0.630 \\
\hline \multirow{5}{*}{$\begin{array}{l}\text { Personal/ } \\
\text { Social }\end{array}$} & BT & 3.08 & 1.78 & 3.50 & 1.98 & 62.00 & 0.590 \\
\hline & Day 30 & 3.08 & 1.78 & 3.67 & 1.83 & 59.00 & 0.478 \\
\hline & Day 60 & 3.17 & 1.64 & 4.00 & 1.60 & 51.00 & 0.242 \\
\hline & AT & 3.75 & 1.48 & 4.50 & 1.38 & 51.50 & 0.242 \\
\hline & $\mathrm{AF}$ & 3.75 & 1.48 & 4.50 & 1.38 & 51.50 & 0.242 \\
\hline \multirow{5}{*}{ Mental status } & BT & 1.08 & 0.67 & 1.25 & 0.87 & 65.50 & 0.713 \\
\hline & Day 30 & 1.08 & 0.67 & 1.42 & 0.79 & 56.00 & 0.378 \\
\hline & Day 60 & 1.17 & 0.72 & 1.58 & 0.67 & 52.00 & 0.266 \\
\hline & AT & 1.42 & 0.67 & 1.67 & 0.65 & 55.50 & 0.347 \\
\hline & $\mathrm{AF}$ & 1.42 & 0.67 & 1.67 & 0.65 & 55.50 & 0.347 \\
\hline \multirow{5}{*}{ Language } & BT & 1.92 & 1.38 & 2.83 & 1.80 & 52.00 & 0.266 \\
\hline & Day 30 & 1.92 & 1.38 & 2.83 & 1.80 & 52.00 & 0.266 \\
\hline & Day 60 & 1.92 & 1.38 & 3.00 & 1.65 & 45.00 & 0.128 \\
\hline & AT & 2.33 & 1.07 & 3.33 & 1.56 & 46.50 & 0.143 \\
\hline & $\mathrm{AF}$ & 2.33 & 1.07 & 3.33 & 1.56 & 46.50 & 0.143 \\
\hline \multirow{5}{*}{ Performance } & BT & 0.25 & 0.62 & 0.33 & 0.78 & 71.00 & 0.977 \\
\hline & Day 30 & 0.25 & 0.62 & 0.33 & 0.78 & 71.00 & 0.977 \\
\hline & Day 60 & 0.25 & 0.62 & 0.83 & 0.83 & 42.50 & 0.089 \\
\hline & AT & 0.50 & 0.80 & 1.00 & 0.74 & 45.00 & 0.128 \\
\hline & $\mathrm{AF}$ & 0.50 & 0.80 & 1.00 & 0.74 & 45.00 & 0.128 \\
\hline \multirow{5}{*}{ Memory } & BT & 0.33 & 0.89 & 1.00 & 1.71 & 58.50 & 0.443 \\
\hline & Day 30 & 0.33 & 0.89 & 1.00 & 1.71 & 58.50 & 0.443 \\
\hline & Day 60 & 0.33 & 0.89 & 1.08 & 1.68 & 53.00 & 0.291 \\
\hline & AT & 0.42 & 1.00 & 1.25 & 1.66 & 48.50 & 0.178 \\
\hline & $\mathrm{AF}$ & 0.42 & 1.00 & 1.25 & 1.66 & 48.50 & 0.178 \\
\hline \multirow{5}{*}{$\begin{array}{c}\text { Teacher } \\
\text { drooling scale }\end{array}$} & BT & 1.00 & 1.13 & 0.92 & 1.08 & 68.50 & 0.843 \\
\hline & Day 30 & 0.75 & 0.87 & 0.83 & 1.03 & 70.50 & 0.932 \\
\hline & Day 60 & 0.67 & 0.78 & 0.58 & 0.67 & 69.00 & 0.887 \\
\hline & AT & 0.17 & 0.39 & 0.25 & 0.45 & 66.00 & 0.755 \\
\hline & $\mathrm{AF}$ & 0.17 & 0.39 & 0.25 & 0.45 & 66.00 & 0.755 \\
\hline
\end{tabular}

No significant difference was found in any milestone parameter between the groups at any time in follow ups.

\section{Discussion on Therapeutic Observations and Results}

In Ayurveda symptoms of cerebral palsy can be correlated with vata vyadhi. As we know that main function of vata is "pravartakschchestanamucchvachanam". (functions related to nervous system), whenever the vata gets vitiated, the normal functions of vata derange. ( Ch.Su.12)Delayed development of gross and fine motor function may be due to a problem in normal function of Vata. Hence, to achieve results in developmental disorders, function of Vata (normal physiology) should come to normal. Here, Ashtamangal Ghrita might have worked on central nervous system (CNS) by crossing BBB (Blood Brain Barrier-Majja Dhara Kala) because of its lipophilic property, thus stimulating higher mental functions (Medha, Smriti and Buddhi). Abhyanga and Swedana caused Dosha gati from Shakha to Koshtha. Thus by the combined effect of total therapeutic measures, Majja got nourishment, Vata came to normalcy, and hence the proper development of milestones were achieved.

Significant improvement was found in both the groups in spasticity. Spasticity is characterized by increased resistance by passive stretch, velocity dependent, and asymmetric about joints (i.e. greater in flexor muscle at the elbow and the extensor muscle at the knee)(13). Spasm was reduced significantly, which may be due to Shamana of Vata Guna like Chala and Shita by virtue of Ashtamangal Ghrita, Abhyanga and Sweda. Abhyanga \& shashtikashalipinda sweda also act by increasing blood circulation. This facilitating transdermal drug absorption \& receiving beneficial effects of respective drugs. Shashtika shali is snigdha, sthira, balavardhaka. Bala, go dugdha \& dashmoola are snigdha, rasayana, balya \& vatahara. Thus by virtue of these properties of drugs \& increased blood circulation spasticity was decreased \& tissue extensibility increased facilitating ease of motion.

Significant improvement were found on Language in both the Groups although Group B shows 
slightly superior results than group A. Language is more of the function of Udana Vayu, which is normally situated at Uraha Pradesha(chest region)(14), showed significant result in this study in both groups. As this disease entity comes under chronic problem, the study period may not be enough to show the complete correction of language.

Effect of Treatments on Teacher drooling scale showed significant improvement in both the Groups. Group A showed slightly superior results than group B. Saliva production is almost completely controlled by the autonomic nervous system both sympathetic \& parasympathetic. In $\mathrm{CP}$ primary functions such as lip closure, intra oral tongue suction \& swallowing may be disturbed as a result of neurodevelopmental delay. On the basis of overall pharmacological activity of Ashtamangal ghrita it has medhya \& vatahara properties. Besides these it also has neuroprotective activity. Due to all these properties of drug there was significant improvement in brain functions \& thus showing improvement in excessive salivation.

Previously it was believed that neurons do not repair or rejuvenate after any injury, but the new concept of neuroplasticity says that CNS have the ability to repair their neurons by axonal sprouting to take over the function of damaged neurons.(15) This improvement in patients also supports the concept of Neuroplasticity.

The rationality behind taking ghrita as a base is to extract or hold lipid soluble active fraction from the ingredients used. When it taken internally it enters into the systemic circulation \& can easily cross the blood brain barrier, thereby strengthens or stimulate the CNS. On evaluation of ayurvedic pharmacodynamics properties of Ashtamangal ghrita's ingredients, the predominant ayurvedic pharmacodynamic properties of Ashtamangal ghrita were madhura, katu, tikta rasa, guru, snigdha \& laghu guna, madhura \& katu vipaka, ushna \& sheeta veerya, tridosha shamak, medhya prabahv \& jathragni deepak.

Madhura rasa is sarvadhatuvardhaka, brihmana, jeevniya, preenan, sthairykaran. Madhura rasa is formed by prithvi \& jala mahabhuta. The panchbhautika composition of mamsa dhatu is also jala $\&$ prithvi. This by the principle of samanyam vriddhikaranam, madhura rasa helps in nourishment of mamsa dhatu. Due to sarvadhatu vardhaka guna it provides support \& proper nourishment to neurons. Its ksheenakshata sandhankara guna helps in regenerating damaged neurons. Katu rasa is indriyouttejaka (to stimulate sensory/motor organs to perceive their subjects), agnideepak (secretion of hormones in synaptic vesicles), marganavivrunoti (to create new pathway for proper functioning and replacement of damaged neurons). Tikta rasa also has sthirikarana property (provides strength to muscles \& tissues). Guru \& Snigdha guna are vatahara \& provide nourishment to the body. Ushna veerya acts by vatahara property \& also increases blood circulation in brain while sheeta veerya with stambhana \& sthirikarana property may restrict the excessive neuronal discharge seen in case of convulsions. Madhura vipaka has vatahara property \& its panchbhautika composition is prithvi and jala. Thus, same as madhura rasa it also acts by the principle of samanyam vriddhikaranam \& helps in nourishment of mamsa dhatu.

Comparison of the results shows that Nasya of ashtamangal Ghritawas found better than oral administration. Nasya is specifically designed route for shirorogas. It has very significant role on diseases of murdha, netra, shrotra, kantha, etc. Central nervous system consists of the brain and spinal cord. It integrates different kinds of sensory information, emotions, thoughts and memories. It is protected blood brain barrier and blood C.S.F. barrier. C.N.S. diseases have a great challenge for entry of medicine into brain tissue. The capillary endothelial cells in the brain have tight junctions. Blood brain barrier (B.B.B.) protects brain cells from harmful substances and pathogens by preventing passage of many substances from blood to brain tissue. It permits certain substances to enter C.S.F. but exclude others. Both these barriers are lipoidal \& limit the entry of non-lipid soluble drugs. In nasya, there is direct entry of medicine into C.N.S. According to ayurved, nose is entrance for head. Drugs administered through nose spreads over Shrungatak marma (Cavernous sinus) as well as channels within head, nose, throat and removes vitiated doshas. Nasya is the best treatment for shirorogas as it goes faster to target organ and bypass the first metabolism. There is close relationship between nose and brain which is also accepted by modern science. Anatomical \& physiological study of nose shows that nasal mucosa (olfactory mucosa) is the only site which directly connects brain \& external environment. Drug administered through nose gets absorbed through three ways -through nasal mucosa and vascular pathway.

By these routes drug have direct entry into C.N.S. and crosses the BBB. As the study drug, Ashtamangal ghrita was in lipid form, it also facilitated drug absorption. This also facilitated the absorption of medicine through mucous membrane and capillaries. According to pharmaceutical research, lipid soluble drugs diffuse by dissolving in lipoid matrix of membrane. Lipid soluble drugs pass readily across the whole surface of the capillary endothelium. In nasya, recommended position of patient is given as supine with head tilted. Due to this, drug molecules come in closer contact with olfactory mucosa which is the alleyway for medicine.(16)

\section{Conclusion}

Cerebral palsy includes a group of nonprogressive and non-contagious disorders causing physical disability mainly in the various areas of body movement. Currently there is no cure for CP. But use of ayurvedic management can reduce the muscle tone, increases the range of motion of the joints, improves the function of upper and lower extremities, delays the need for surgery \& thus improving the life style \& activities of daily life.

In the present clinical trial significant results were found in all the parameters except memory in both 
groups i.e. oral administration of Ashtamangal ghrita in group A \& nasya of Ashtamangal ghrita in group B. Quality of life was improved in most of the patients in both groups due to reduction in spasticity \& improved power. Overall effect of therapy shows that there was $34.79 \%$ improvement in group A \& $37.74 \%$ improvement in group B. Results were slightly superior in group B than group A in most of the parameters. In group B nasya of Ashtamangal ghrita and Shastikashali pinda sweda were used. Although most of the parameters in group B show slightly superior result than group A but intergroup comparison of both groups was not-significant or there were no differences in both groups statistically..Group A was slightly superior than group B in following parameters -Head holding, sitting and teacher's drooling scale. Except these parameters, in all the other parameters group B was slightly superior than group A. There were no any significant mean changes in all the parameters after 1 month of follow up period without intervention of treatment which shows the persistent effect of the therapy in both the groups. No untoward effects of any drug or procedure were noticed during or after the trial.

\section{References}

1. Ghai O.P., V.K. Paul, Arvind Bagga. Ghai Essential Pediatrics. 8th Edition, CBS Publisher, New Delhi; 2013. 581p.

2. Ghai O.P., V.K. Paul, Arvind Bagga. Ghai Essential Pediatrics. $8^{\text {th }}$ Edition, CBS Publisher, New Delhi; 2013. 582p.

3. Odding E, Roebroeck ME, Stam HJ. The epidemiology of cerebral palsy: Incidence, impairments and risk factors. Disabil Rehabil. 2006;28:183-91.- PubMed

4. Boyle CA, Yeargin-Allsopp M, Doernberg NS, Holmgreen P, Murphy CC, Schendel DE. Prevalence of selected developmental disabilities in children 3-10 years of age: The Metropolitan Atlanta Developmental Disabilities Surveillance Program, 1991. MMWR CDC Surveill Summ 1996; 45:1-14. - PubMed

5. Shastry K, Chaturvedi G. Charak Samhita chikitsasthana 28/2 with "Vidyotini" Hindi commentary. Chaukhambha Bharati Academy; 1996. p. 806. Part 1. [Google Scholar]

6. Shastry K, Chaturvedi G. Charak Samhita sutra sthana 20/11with "Vidyotini" Hindi commentary. Chaukhambha Bharati Academy; 1996. p. 806. Part 1. [Google Scholar]

7. Gupta KA. Ashtanga Hridaya uttartantra 3/10 with Vidyotini Hindi commentary. Varanasi: Chaukhambha Sanskrit Sansthan; 1997. "Vidyalankar, Bhishagratna" [Google Scholar]

8. Sushruta Samhita, Sharir Sthana 2/33, Sushruta Samhita. Edited by Ambika Datta Shastri. Sharirasthana Varanasi: Chowkhamba Sanskrit Series, 14th edition, 2004, 10/68-70.

9. Shastry K, Chaturvedi G. Charak Samhita, Sutra Sthana 4/15with "Vidyotini" Hindi commentary. Chaukhambha Bharati Academy; 1996. p. 806. Part 1. [Google Scholar]

10. Shastry K, Chaturvedi G. Charak Samhita, Sutra Sthana 4/18with "Vidyotini" Hindi commentary. Chaukhambha Bharati Academy; 1996. p. 806. Part 1. [Google Scholar]

11. Shastry K, Chaturvedi G. Charak Samhita, Sutra Sthana, 4/27with "Vidyotini" Hindi commentary. Chaukhambha Bharati Academy; 1996. p. 806. Part 1. [Google Scholar]

12. Shastry K, Chaturvedi G. Charak Samhita, Sutra Sthana 8/31 with "Vidyotini" Hindi commentary. Chaukhambha Bharati Academy; 1996. p. 806. Part 1. [Google Scholar]

13. Dictionary Spasticity. [Last cited on 2012 Mar 15]. Available from:http://www.dictionary.webmd.com/ terms/spasticity .

14. Gupta KA. Ashtanga Hridaya, Sutra Sthana, Doshabhediya 12/5. with Vidyotini Hindi commentary. Varanasi: Chaukhambha Sanskrit $\mathrm{S}$ a n s than; 1997 . "Vid y a lan kar, Bhishagratna" [Google Scholar]

15. Trojan S, Pokorný J. Theoretical aspects of neuroplasticity. Physiol Res. 1999; 48:87-97

16. Deshpande Gayatri S, Joshi Abhijeet, Hypothetical Evaluation of Action of Nasya on Central Nervous System. International Ayurveda Medical Journal. Volume 2; Issue 4; July - August-2014, 607-612. 